\title{
A note on the biostratigraphic application of Permian plant fossils of the Normandien Formation (Beaufort Group, Northeastern Main Karoo Basin), South Africa
}

\author{
Marko Claassen \\ Department of Geology, University of Pretoria, Pretoria 0002, South Africa \\ e-mail: marko.claassen@up.ac.za
}

() 2008 September Geological Society of South Africa

\begin{abstract}
Two new assemblages (farms Christina and Moorfield) of plant fossils belonging to the Glossopterid flora are described from the northeastern part of the Main Karoo basin, within the Late Permian Normandien Formation, Beaufort Group, Karoo Supergroup. The Normandien Formation comprises three sandstone members (lower Frankfort, Rooinek, upper Schoondraai) each overlain by an argillaceous interval. Two informal plant fossil assemblage zones are distinguished in the field: a "Christina assemblage zone" defined by Morphotype Pnc1, Morphotype Pnc2, Morphotype Pnc3 and Morphotype Pnc7, between the Frankfort and Rooinek sandstones; a younger "Moorfield assemblage zone" between the Rooinek and Schoondraai sandstones, defined by Morphotype Pnm1, Morphotype Pnm2, Morphotype Pnm3, Rigbya arberioides and Sphenophyllum speciosum. These two proposed plant fossil assemblage zones enable subdivision of the Dicynodon therapod assemblage zone coincident with the Normandien Formation, and the two plant fossil zones have been successfully mapped out over a large area.
\end{abstract}

\section{Introduction}

The Gondwana supercontinent is synonymous with the Karoo sedimentation and terminal volcanism, preserved in countless basins and rifts within many of the presentday dispersed continents (e.g., Catuneanu et al., 2005). The Gondwana period saw the rise of the vascular plants, the dominance of the amphibians and the mammal-like reptiles (therapsids) and the emergence of the dinosaurs (e.g., Anderson and Anderson, 1985). The Main Karoo basin of South Africa is generally accepted as the global type-section of Karoo-Gondwana sedimentation (e.g., Cairncross, 2001), comprising Late Carboniferous basal glacigenic deposits of the Dwyka Formation, basinal-deltaic-fluvial deposits of the Ecca Group, essentially alluvial-fluvial sandstones and mudrocks of the Beaufort Group, followed by the humid-fluvial Molteno, semi-arid fluvial-loessic Elliot and desert sediments of the Clarens Formations (e.g., Smith et al., 1993; Johnson et al., 1996; Catuneanu et al., 2005). Gondwana break up followed upon eruption of the widepsread Drakensberg lavas (e.g., Marsh et al., 1997 ) at 200 to $180 \mathrm{Ma}$ (Condie, 2002). In contrast to earlier interpretations of the Main Karoo basin as a unitary subsiding basin, Catuneanu et al. (1998) argue in favour of a flexural foreland basin, in which the Karoo sedimentary fill was controlled by eight orogenic cycles of loading and unloading in the Cape fold belt to the south.

The Beaufort Group of the Main Karoo basin covers a significant portion of South Africa, is about $3 \mathrm{~km}$ thick, and comprises a highly fossiliferous succession of mudrocks and lesser sandstones. The Middle Permian to Middle Triassic age of the Beaufort place it in a period when globally, the stem lineages of mammals and dinosaurs evolved (Hancox and Rubidge, 2001).
The very well documented sedimentary and palaeontological record (e.g., Kitching, 1977; 1978; Rubidge, 1995) of this group in South Africa have led to a widespread, although not exclusive acceptance of it being the global biostratigraphic standard for the non-marine Permo-Triassic period (Shishkin et al., 1995; Lucas, 1998; Hancox and Rubidge, 2001). Its stratigraphic record obviously also encompasses the end-Permian mass extinction, the largest such event known (Erwin, 1994).

In terms of global plant diversity, the Permian was characterised by the dominance of the glossopterids (Ottokariales) within an average to lower diversity, and a transition from cool to warm palaeoclimatic conditions (Anderson et al., 1999). The peak of Gondwana-Laurasia supercontinent assembly in the Late Permian was accompanied by a global sea level lowstand (Scotese, 1997), and by global warming which likely climaxed in the Middle to Late Triassic (Turner, 1999). Under these favourable palaeoclimatic conditions, the glossopterid plants spread throughout Gondwana, with peak diversity being attained in the Late Permian (Anderson et al., 1999). A very large literature on the order Glossopteris has yet to resolve issues of classification and nomenclature (e.g., Pigg and Trivett, 1994). For this study the (Manual for leaf Architecture Working Group 1999) were used to describe Laeves, shapes venation, as well as leaf size

The Beaufort Group contains very limited basin-scale lithological marker beds and contacts tend to be diachronous (Hancox and Rubidge, 2001). However, tetrapod fossils are abundant enough in the Beaufort to have enabled well constrained subdivision into eight faunal assemblage zones (Table 1), which have greatly facilitated basin analysis of this unit (e.g., Rubidge, 1995; 


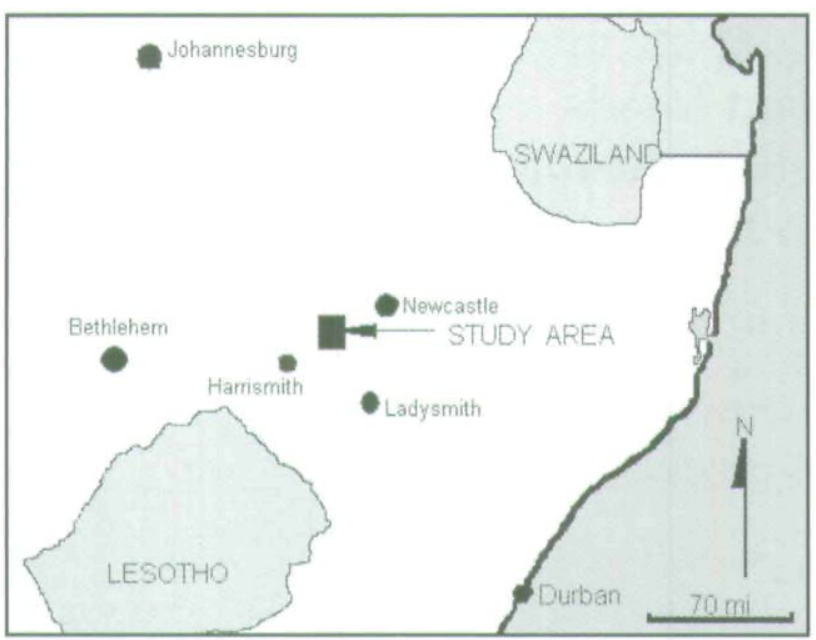

Figure 1. Map showing extent of the Beaufort Group (Karoo Supergroup) within South Africa (top) as well as the location of the study area. Note Dicynodon biostratigraphic zone, within which the study area falls. The lower map is a more detailed one of the study area itself: note farms Christina and Moorfield, Normandien and Miller's Passes, and Newcastle.

Hancox and Rubidge, 1997; Catuneanu et al., 1998; 2005; Catuneanu and Bowker, 2001). The rich fossil fauna of the Beaufort has also allowed detailed palaeoenvironmental and taphonomic studies to be carried out (e.g., Smith 1990; Hancox, 1998). In palaeontological research in the Beaufort sediments, investigations of flora and even more so of their stratigraphic significance have been relatively neglected. Tetrapod-based biostratigraphy has always tended to overshadow inferences presented by the plant fossil finds (e.g., Hancox and Rubidge, 2001). Plant macrofossils and their importance (Anderson and Anderson 1993; 1997) and palynology (MacRae and Aitken, 1997) have been well reviewed, and Bamford (1999) has used fossil wood from the Beaufort for biostratigraphic interpretation.

In this paper, plant fossils collected at two new assemblages in the northern Free State, will be documented. These assemblages are to the north of any previous collecting assemblages (Anderson and Anderson, 1985); they fall within part of an area mapped for the Council for Geoscience by Groenewald (1989), who also noted various animal and plant fossils within the Beaufort succession in this region. The Beaufort Group in this northern Free State study region (Figure 1) encompasses a lower Normandien Formation, equated with the Dicynodon assemblage zone (Table 1), overlain by the Verkykerskop and Driekoppen Formations. Detailed field work over a number of years in the Normandien Formation provides a basis for a more detailed biostratigraphic subdivision of the medial part of this assemblage zone, based on fossil flora, detailed in this contribution. The two proposed informal "palaeofloral biozones" within the Dicynodon assemblage zone within the Normandien Formation of the study area have been followed in the field over a large area, to confirm the potential validity of the proposed new biostratigraphy. As part of this, the study area has been remapped as well, utilising the proposed new biostratigraphic subdivision (see Figure 7).

\section{Location of the study area, general geology and} previous work

The study area is situated in the northeastern Free State and north western KwaZulu natal, South Africa, with detailed fieldwork largely on the farms Christina (90) and Moorfield (9194), plus several other farms Beginsel (1284), Ons Huis (780), La Hochs Hoek (262), Insigt (1416), Moorfield (9194) and on the Normandien Pass - along the Drakensberg escarpment in the general area between Normandien Pass and Miller's Pass (Figure 1). This area is between 20 and $35 \mathrm{~km}$ from the large town of Newcastle. Detailed plant collections were made on the Christina and Moorfield farms and other farms on the Drakensburg escarpment, and represent new collection assemblages for Glossopteris fossils within the northeastern Karoo basin.

The Beaufort Group of the Main Karoo basin is subdivided into lower Adelaide and upper Tarkastad Subgroups, with both thinning towards the northeast of the basin (including the study area) and the latter only being found east of $24^{\circ} \mathrm{E}$. Within this northeastern part of the basin (see study area, Figure 1), the Karoo succession comprises the lowermost Volksrust Formation (Ecca Group), following Normandien and Verkykerskop, and uppermost Driekoppen Formations (Table 1). The upper Normandien Formation unconformity with the lower Harrysmith member is equated with the Permian-Triassic boundary (Ward, 2005), and this paper focuses on the former unit. The Normandien Formation within the study area consists of three sandstone members, Frankfort, Rooinek and Schoondraai, each overlain and separated by argillaceous intervals (Table 1). The rich reptilean fauna of the Beaufort Supergroup has led to a well established biostratigraphic subdivision (e.g., Rubidge, 1995), with the larger part of the Normandien Formation being equivalent to the long-ranging Dicynodon assemblage zone (Table 1). This paper examines the plant fossil material from the two argillaceous successions below and above the Rooinek Member, with the aim of establishing a more detailed subdivision of the Dicynodon assemblage zone based on these fossil finds.

The Beaufort rocks in the study area are intruded by numerous Jurassic dolerite dykes and sills, which have disturbed the otherwise essentially horizontal sedimentary beds, resulting in localised dips up to $7^{\circ}$. Dykes have resulted in a slaty cleavage of metamorphic origin for a few metres either side of the intrusions; sills have produced a more pervasive pattern of alteration to baked mudrocks and partly recrystallised sandstones. The Normandien Formation is underlain by the Volksrust Formation of the Ecca Group. The latter unit comprises poorly outcropping carbonaceous mudrocks and grades up into the basal Normandien lithologies. The Normandien itself encompasses the three 
Table 1. Lithostratigraphy and chronostratigraphy of the Beaufort Group, showing dinosaur fossil assemblage zones and correlation between different portions of the Main Karoo basin (modified after Rubidge, 1995; Hancox and Rubidge, 2001). Note Normandien Formation, its three sandstone members (Frankfort, Rooinek and Schoondraai) separated by two argillaceous intervals (the "Christina" and "Moorfield plant fossil assemblage zones" suggested in this paper), and the overall correlation of this formation with the Dicynodon assemblage zone.

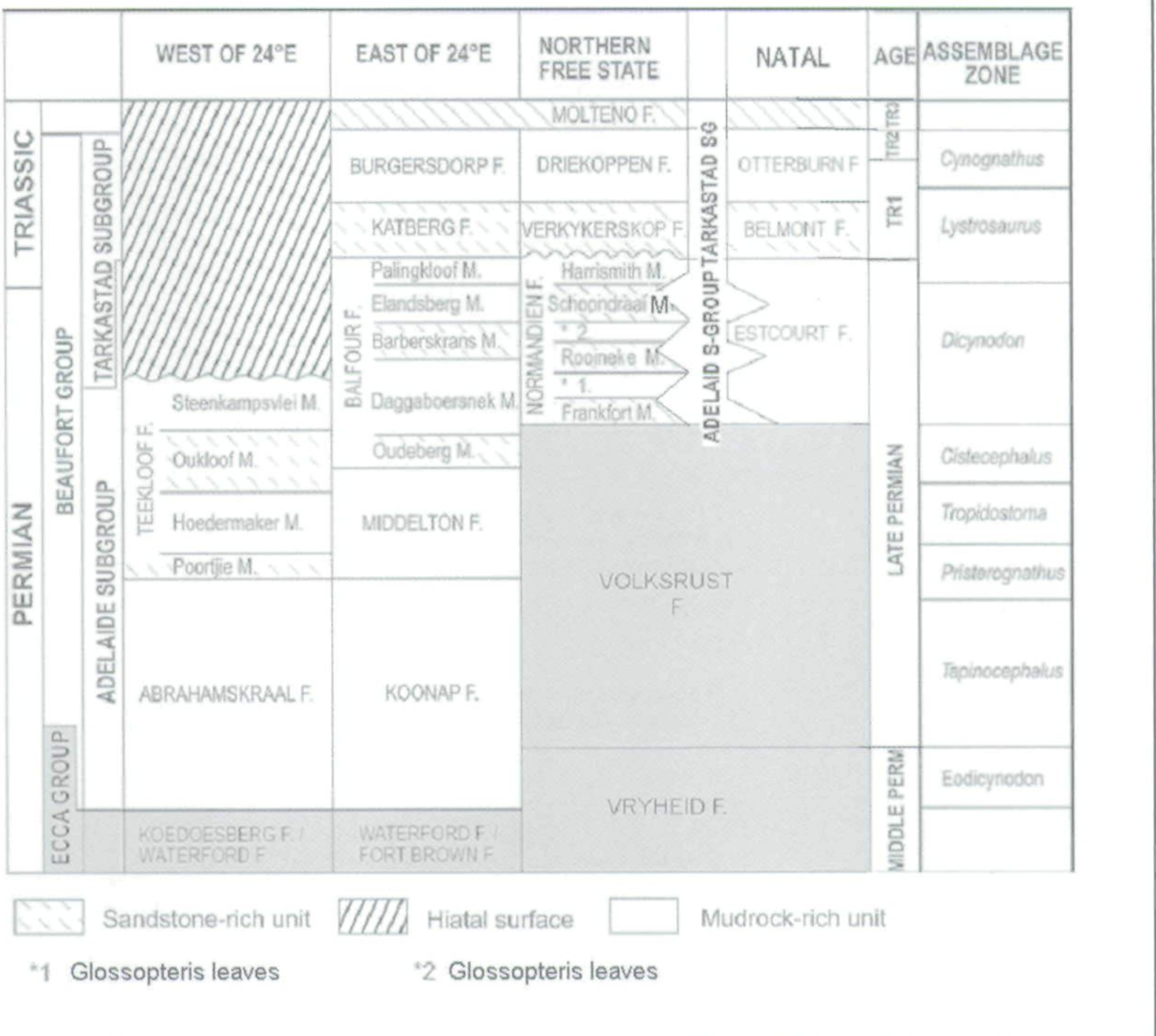

feldspathic sandstone members, Frankfort (30 to $50 \mathrm{~m}$ thick), Rooinek (lenticular geometry; 4 to $21 \mathrm{~m}$ thick), Schoondraai ( 3 to $15 \mathrm{~m}$ ), with predominantly greencoloured mudrocks between them, except for the strongly red argillaceous rocks of the uppermost Harrismith Member (Figure 2) (Groenewald, 1989). A detailed investigation of the lithostratigraphy, sedimentology and palaeontology of the northeastern Free State, including the area discussed here, was carried out by Groenewald (1989) and forms the basis for the general description of the geology provided here, augmented by detailed field observations by the author.

The basal Frankfort Member comprises a relatively large number of upward-coarsening mudrock interbedded mudrock-sandstone - fine- to mediumgrained sandstone cycles. Sandstones vary between
$15 \mathrm{~cm}$ and $5 \mathrm{~m}$ in thickness and are commonly bioturbated, with abundant Planolites and Scolithos burrows. At the top of the member, an argillaceous zone including a $150 \mathrm{~cm}$ thick carbonaceous mudstone layer, is sharply overlain by an uppermost upward-fining sandstone which grades into the mudrocks (c. $60 \mathrm{~m}$ thick) separating the Frankfort from the medial Rooinek Member. Groenewald (1989) reported impressions of undifferentiated Glossopteris leaves on mudrock bedding planes throughout the Frankfort member. The thick, predominantly green-coloured mud rocks which succeed the Frankfort Member contain interbedded mudrock-sandstone strata as well as cross-stratified fineto medium-grained sandstone beds up to $1 \mathrm{~m}$ thick. These sandstones tend to be strongly erosively-based and the mudrocks again exhibit Glossopteris leaf impressions. According to Groenewaldt (1989), a $150 \mathrm{~cm}$ 
(M)

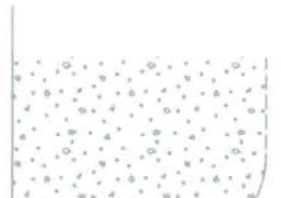

Verkykerskop Formation - sandstones

45

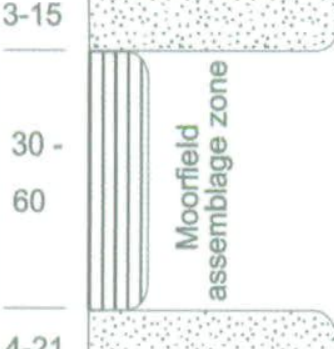

4-21

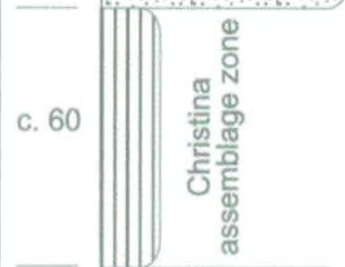

30

50

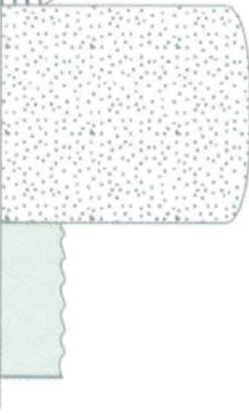

Red-coloured silty mudrocks with subordinate sandstones

erosively-based fine- to medium-grained sandstones; Schoondraal minor mudrocks Member

Predominantly green mudrocks with sandstone interbed and minor carbonaceous mudrocks/coal; beds

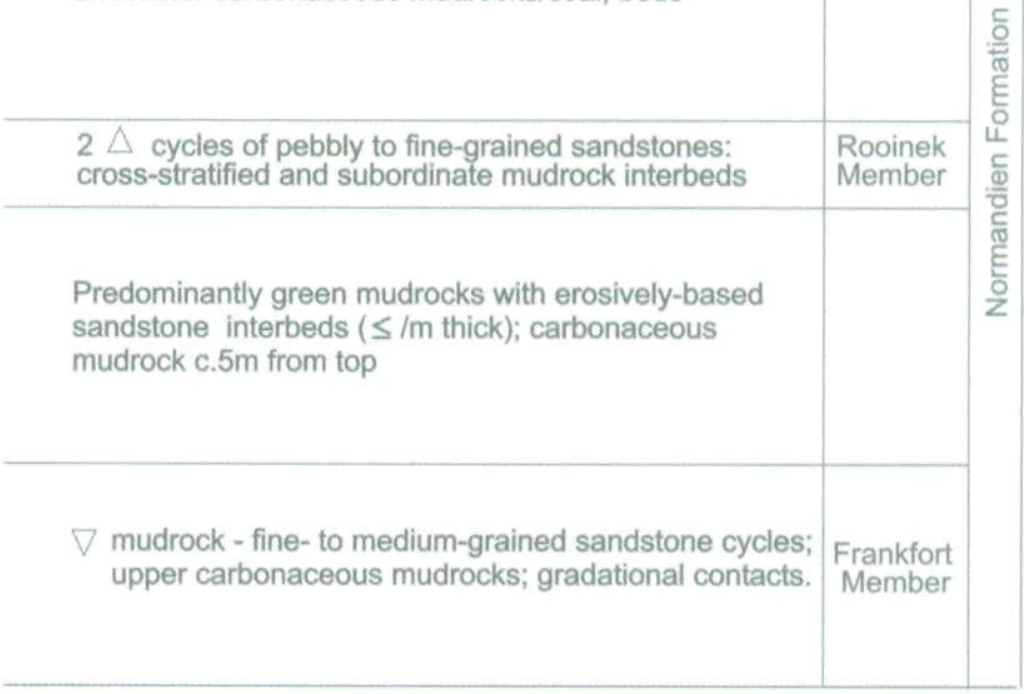

Volksrust Formation - carbonaeous mudrocks

Figure 2. Lithostratigraphy of the Normandien Formation from the study area. Note three sandstone members (Frankfort, Rooinek and Schoondraai), separated by a green and grey-coloured argillaceous intervals, from which the fossil collections discussed here were obtained. Modified after Groenewald (1989), based on field work of the author.

thick horizon of carbonaceous mudrock outcrop about $5 \mathrm{~m}$ below the upper contact with the overlying the Rooinek member.

Two upward-fining cycles of small-pebbly to finegrained sandstone, displaying cross-stratification, characterise the Rooinek Member; subordinate mudrock interbeds again have Glossopteris fossils. A c. $30 \mathrm{~m}$ thick argillaceous interval succeeds this member, separating it from the next significant sandstones of the Schoondraai Member. This muddy interval encompasses two $50 \mathrm{~cm}$ thick carbonaceous mudstone interbeds, a few lenses of fine- to medium-grained sandstones in its basal portion, and a prominent green-coloured upper mudstone interval. Fossils include the relatively large reptilian skulls of Dicynodon lacerticeps and Glossopteris leaves (Groenewald, 1989). Upward-fining, medium- to finegrained, erosively-based sandstones with subordinate green mudstones characterise the third arenaceous member, Schoondraai (Figure 2). This unit is terminated by an interval of alternating mudrocks and sandstones with an upermost coarse-grained sandstone. The final unit of the Normandien Formation is the Harrismith Member, consisting of variously coloured (green, purple, yellow, red) silty mudstones with subordinate planar laminated and cross-stratified fine sandstones (Groenewald, 1989). The basal erosional contact of the overlying Verkykerskop Formation provides a distinct upper termination to the Normandien Formation, 


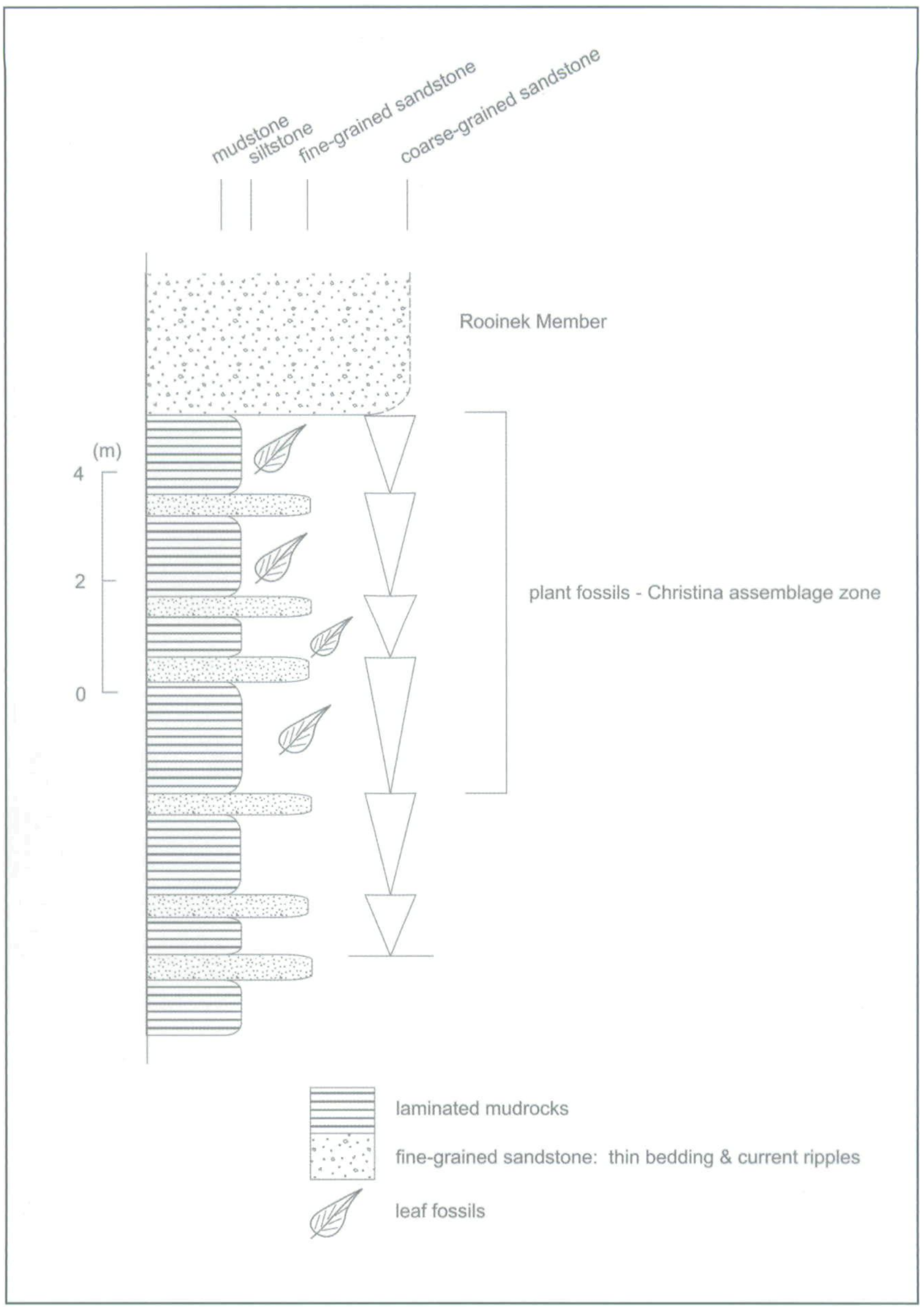

Figure 3. Detailed sedimentary profile measured through the upper $10 \mathrm{~m}$ of the argillaceous succession below the Rooinek Member, Normandien Formation in the study area. Note upward-coarsening mudrock-sandstone cycles and location of leaf fossil occurrences. 

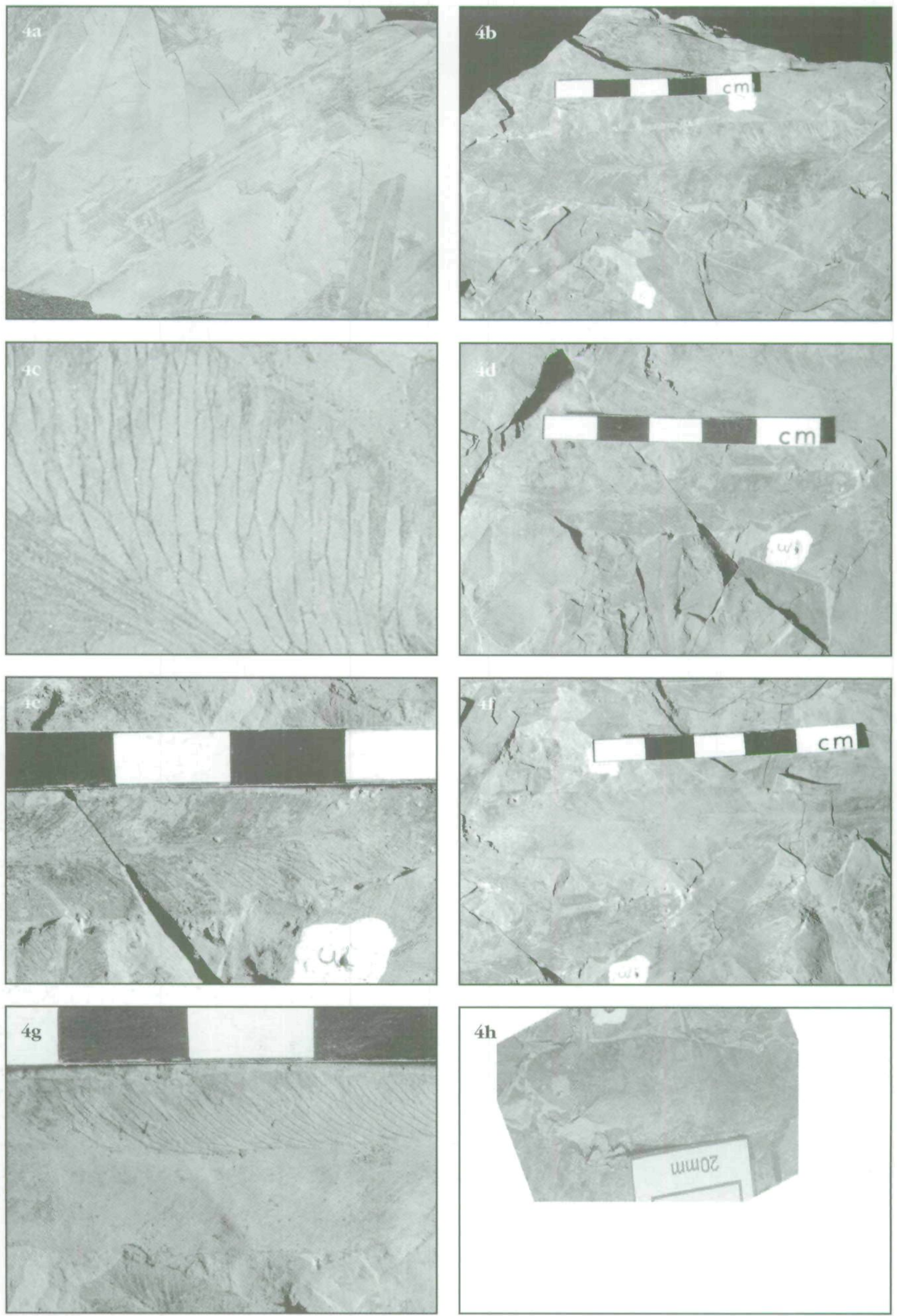

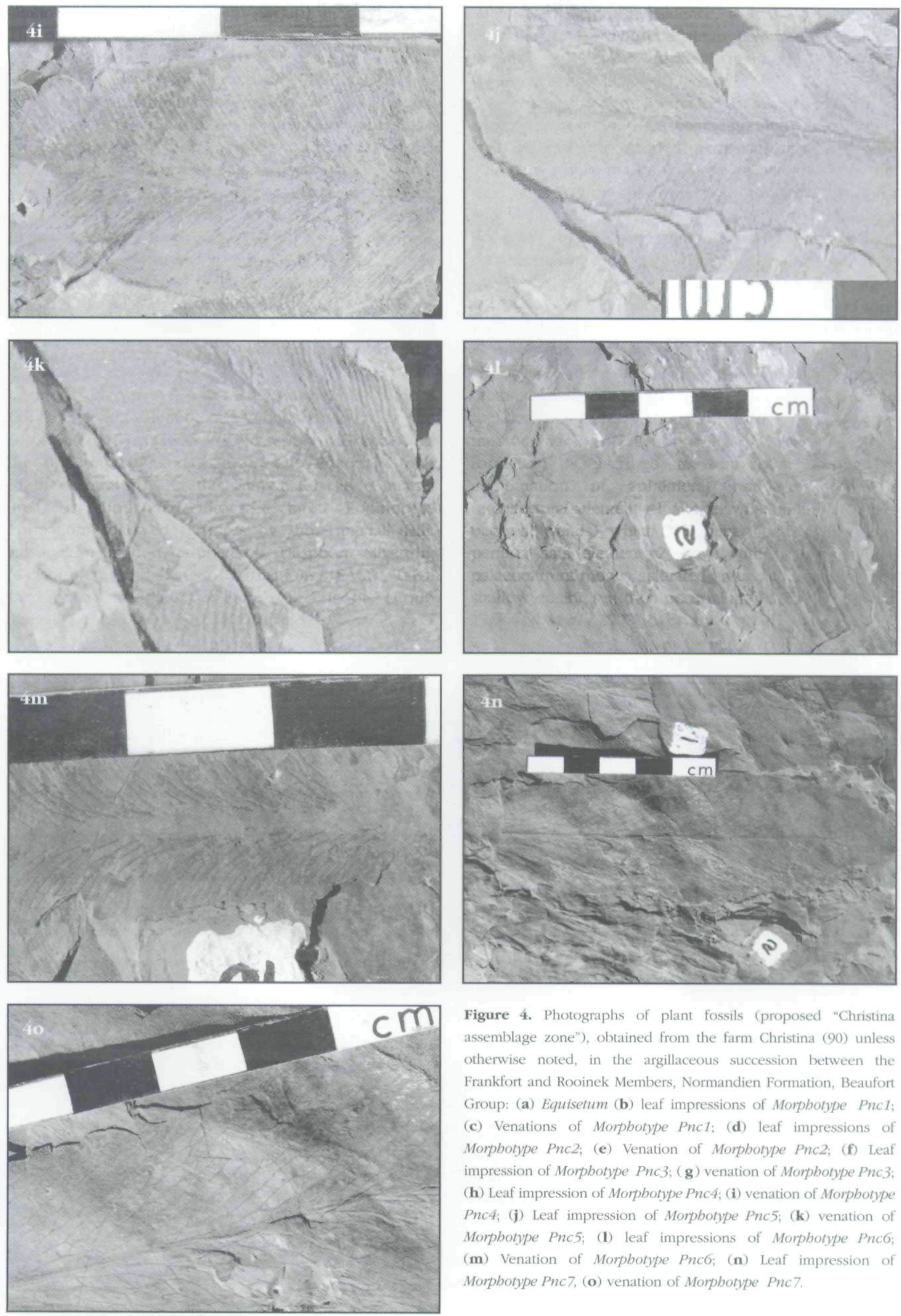

Figure 4. Photographs of plant fossils (proposed "Christina assemblage zone"), obtained from the farm Christina (90) unless otherwise noted, in the argillaceous succession between the Frankfort and Rooinek Members, Normandien Formation, Beaufort Group: (a) Equisetum (b) leaf impressions of Morphotype Pnc1; (c) Venations of Morpbotype Pnc1; (d) leaf impressions of Morphotype Pnc2; (e) Venation of Morphotype Pnc2; (f) Leaf impression of Morphotype Pnc3; ( $\mathbf{g}$ ) venation of Morphotype Pnc3; (h) Leaf impression of Morphotype Pnc4; (i) venation of Morphotype Pnc4; (j) Leaf impression of Morpbotype Pnc5; (k) venation of Morphotype Pnc5; (1) leaf impressions of Morphotype Pnc6; (m) Venation of Morphotype Pnc6; (n) Leaf impression of Morphotype Pnc7, (o) venation of Morphotype Pnc7. 
coincident with the Permian-Triassic boundary (Figure 2; Hancox and Rubidge, 2001).

Groenewald (1989) interprets the basal Frankfort Member of the Normandien Formation as deltaic, with distributary channel sandstones having been subject to bioturbation; this palaeoenvironment is envisaged to have succeeded the prodelta deposits of the underlying Volksrust Formation (Ecca Group) (Catuneanu et al., 1998). The Frankfort delta plain deposits continued into the lower part of the succeeding argillaceous interval in the Normandien, passing up into an inferred meandering river system where floodplain and swamp components were preferentially present over small channel-fill complexes (Groenewald, 1989). The two upper sandstone members, Rooinek and Schoondraai are seen by this author to reflect sandy meander channel-fill complexes, again separated by an argillaceous interval ascribed predominantly to an interchannel floodplain setting. A similar floodplain model is interpreted for the uppermost, muddy Harrismith Member, but with evidence for drier palaeoclimatic conditions (Groenewald, 1989).

Other workers have interpreted the Beaufort Group rocks in the northeast of the Main Karoo basin as products of similar palaeoenvironmental conditions. The basal Frankfort Member deltaic systems probably debouched into lacustrine flood basins (Cadle, 1974; Van Dijk et al., 1978; Turner, 1986). A remnant of the preexisting shallow Ecca epeiric sea, most likely $<50 \mathrm{~m}$ deep, also persisted within the northeast of the basin, but not in the present study area (Smith et al., 1993). Presence of the therapsid zone fossil Dicynodon lacerticeps throughout the Normandien Formation of the study area (Groenewald, 1989; present field work) indicates that this formation can be correlated biostratigraphically with the Balfour Formation in the southeast of the Main Karoo basin (Smith et al., 1993). The humid fluvio-lacustrine palaeoenvironment inferred for the latter contrasts with evidence for aridification of the meandering river floodplain settings within the Normandien Formation of the study area. Catuneanu et al. (1998) similarly interpret the Normandien strata as reflecting a meandering stream environment with adjacent predominant floodplains subject to aridification.

\section{Field data}

\section{Farm Christina (90) Glossopteris assemblage}

This fossil assemblage is centered on Christina, but fossils were collected and identified on several adjacent properties as well (Figure 1). On the farm Christina (90), the argillaceous interval separating the basal Frankfort and Medial Rooinek sandstone members is well exposed. Five upwards-coarsening, gray-coloured mudrock-sandstone cycles can be observed in a sedimentary profile measured through the uppermost 10 meters of this argillaceous interval. The mudrock beds individually stacked are 20 to $60 \mathrm{~cm}$ thick and are finely laminated, whereas the sandstones do not exceed $15 \mathrm{~cm}$ thickness, and comprise fine-grained rocks with thin bedding and current ripple marks. A sixth upwardcoarsening mudrock grades up into a $70 \mathrm{~cm}$ thick sandstone marking the base of the Rooinek Member (Figure 3). The plant fossil collection from this assemblage was obtained from the four topmost mudrock beds, immediately below the Rooinek Member (Figure 3). The leaf fossils here occur within a highly fissile mudrock and the leaves were obviously closely packed when deposited; due to fragmentation of the leaf impressions it was not possible to identify all the fossils occurring at this outcrop. The fossils collected at this assemblage, detailed below in brief formal descriptions, have been identified as belonging to: Equisetum, Morphotype Pnc1, Morphotype Pnc2, Morphotype Pnc3, Morphotype Pnc4, Morphotype Pnc5. Morphotype Pnc6 and Morphotype Pnc7.

Equisetum (Figure 4a): Specimen number: MCL 96/3/1/1. The cylindrical Equisetum shoots, with nodes, occur throughout the Normandien Formation and can therefore not be used for biostratigraphic purposes.

Morphotype Pnc1 (Figure 4. b, c):

\begin{tabular}{|c|c|}
\hline $\begin{array}{l}\text { Amount of } \\
\text { identifiable } \\
\text { specimens found }\end{array}$ & $\begin{array}{l}\text { Seventeen samples of this } \\
\text { specimen were found }\end{array}$ \\
\hline Length / width ratio & $6: 1$ \\
\hline Leaf shape & Narrow elliptic. Base cuneate. Apex acute \\
\hline $\begin{array}{l}\text { Base angle at } 25 \% \\
\text { from base }\end{array}$ & $24^{\circ}$ \\
\hline $\begin{array}{l}\text { Apex angle at } 75 \% \\
\text { from base }\end{array}$ & $28^{\circ}$ \\
\hline Venation & $\begin{array}{l}\text { Elongate elliptic meshes, veins closely } \\
\text { spaced, inclined at an intermediate angle } \\
\text { of } 12^{\circ} \text {, and at } 53^{\circ} \text { in the middle of the } \\
\text { lamella, and then forms an almost } \\
\text { straight line towards the leaf margin at an } \\
\text { angle of } 63^{\circ}\end{array}$ \\
\hline Venation density & 9 to 10 per $\mathrm{cm}$ \\
\hline Midrib & $\begin{array}{l}1 \mathrm{~mm} \text { wide at base of lamella, and } \\
\text { tapering persistently towards apex, but } \\
\text { stops just short of the apex }\end{array}$ \\
\hline Localities & $\begin{array}{l}\text { Three sample of this species were found } \\
\text { and collected on the farm Christina ( } 90 \text { ); } \\
\text { other locations where } 12 \text { more samples } \\
\text { were found but not collected, were on } \\
\text { the farms Beginsel (1284), La Hochs } \\
\text { Hoek ( } 262 \text { ), Ons Huis ( } 780 \text { ) and on the } \\
\text { Normandien pass (Figure 1) }\end{array}$ \\
\hline
\end{tabular}

Morphotype Pnc2 (Figure 4d, e):

\begin{tabular}{ll}
$\begin{array}{l}\text { Amount of } \\
\text { identifiable } \\
\text { specimens found }\end{array}$ & $\begin{array}{l}\text { Ten samples of this specimen were } \\
\text { found }\end{array}$ \\
\hline Leaf size & Small, length $84 \mathrm{~mm}$ \\
\hline Length / width ratio & $7.6: 1$ \\
\hline Leaf shape & Narrow oblong, and obtuse apex \\
\hline
\end{tabular}




\begin{tabular}{ll}
\hline $\begin{array}{l}\text { Base angle at } 25 \% \\
\text { from base }\end{array}$ & $22^{\circ}$ \\
\hline $\begin{array}{l}\text { Apex angle at } 75 \% \\
\text { from base }\end{array}$ & $36^{\circ}$ \\
\hline $\begin{array}{l}\text { Venation } \\
\text { Elongated elliptical meshes, get smaller } \\
\text { towards lamella margin, inclined at } \\
\text { medium angle from midrib, } 32^{\circ} \text { at the } \\
\text { midrib, } 68^{\circ} \text { in the middle of the lamella, } \\
\text { and at } 72^{\circ} \text { at the margin; anastomoses } \\
3 \text { to } 5 \text { times from midrib to margin }\end{array}$ \\
\hline \begin{tabular}{l} 
Venation density: 8 to $10 /$ cm \\
\hline Midrib
\end{tabular} & $\begin{array}{l}\text { Midrib very faint at apex, 1.5 mm wide at } \\
\text { base of lamella, and tapering persistently } \\
\text { towards the apex }\end{array}$ \\
\hline $\begin{array}{l}\text { Localities } \\
\text { Camples of this leaf were found and } \\
\text { collected on the farms Christina (90), } \\
\text { Beginsel (1284), Ons Huis (780), } \\
\text { La Hochs Hoek (262), Insigt (1416), } \\
\text { and the Normandien Pass (Figure 1) }\end{array}$
\end{tabular}

\section{Morphotype Pnc3 (Figure 4f, g):}

\begin{tabular}{|c|c|}
\hline $\begin{array}{l}\text { Amount of } \\
\text { identifiable } \\
\text { specimens found }\end{array}$ & $\begin{array}{l}\text { Four samples of this specimen were } \\
\text { found }\end{array}$ \\
\hline Leaf size & Small, $71 \mathrm{~mm}$ long \\
\hline Length / width ratio & $6.5: 1$ \\
\hline Leaf shape & $\begin{array}{l}\text { Narrow oblong - elliptical, with an } \\
\text { obtuse apex and a cuneate base }\end{array}$ \\
\hline $\begin{array}{l}\text { Base angle at } 25 \% \\
\text { from base }\end{array}$ & $26^{\circ}$ \\
\hline $\begin{array}{l}\text { Apex angle at } 75 \% \\
\text { from base }\end{array}$ & $33^{\circ}$ \\
\hline Venation & $\begin{array}{l}\text { Elongated elliptical meshes, arching at } \\
\text { low angle from the midrib - } 32^{\circ} \\
\text { (Figure } 4 \mathrm{c} \text { ); anastomoses } 4 \text { to } 5 \text { times } \\
\text { from midrib to lamella margin }\end{array}$ \\
\hline Venation density & 13 to $15 / \mathrm{cm}$ \\
\hline Midrib & $\begin{array}{l}\text { Midrib is } 1.2 \mathrm{~mm} \text { wide at base of lamella, } \\
\text { and tapers persistently to were the midrib } \\
\text { reaches the apex }\end{array}$ \\
\hline Localities & $\begin{array}{l}\text { On the farms Christina (90); other } \\
\text { locations where eleven more samples } \\
\text { were found but not collected were on } \\
\text { the farms Beginsel (1284), Ons Huis } \\
\text { ( } 780) \text {, Insigt (1416) Christina ( } 90 \text { ), } \\
\text { and on the Normandien Pass } \\
\text { (Figure 1) }\end{array}$ \\
\hline
\end{tabular}

\section{Morphotype Pnc4 (Figure 4h, i):}

\begin{tabular}{ll}
\hline $\begin{array}{l}\text { Amount of } \\
\text { specimen were found } \\
\text { specimens found }\end{array}$ & Twenty five samples of this identifiable \\
\hline Leaf size & Microphyll \\
\hline Length / width ratio & $2.7: 1$ \\
\hline Leaf shape & $\begin{array}{l}\text { Elliptic, attenuated base and apex aptuse- } \\
\text { rounded }\end{array}$ \\
\hline $\begin{array}{l}\text { Base angle at } 25 \% \\
\text { from base }\end{array}$ & $42^{\circ}$ \\
\hline
\end{tabular}

\begin{tabular}{ll}
\hline $\begin{array}{l}\text { Apex angle at } 75 \% \\
\text { from base }\end{array}$ & $51^{\circ}$ \\
\hline Venation & $\begin{array}{l}\text { Long elongated meshes, rapidly forking, } \\
\text { veins closely spaced, inclined at } \\
\text { intermediate angle at midrib, 30 } \\
\text { forms an almost straight line towards the } \\
\text { leaf margin at an angle of } 52^{\circ}\end{array}$ \\
\hline $\begin{array}{l}\text { Venation density } \\
\text { Midrib }\end{array}$ & $\begin{array}{l}\text { Midrib: reaches apex; midrib is } \\
1,2 \text { mm wide at base of lamella, }\end{array}$ \\
& and tapers persistently towards apex \\
\hline Localities & $\begin{array}{l}\text { Farm Beginsel (1284), Ons Huis (780), } \\
\text { La Hochs Hoek (262), Insigt (1416), } \\
\text { Moorfield (9194) and on the Normandien } \\
\text { Pass (Figure 1) }\end{array}$ \\
\hline
\end{tabular}

\section{Morphotype Pnc5 (Figure 4j, k):}

\begin{tabular}{ll}
\hline $\begin{array}{l}\text { Amount of } \\
\text { specimen were found } \\
\text { specimens found }\end{array}$ & Twenty five samples of this identifiable \\
\hline Leaf size & Small, 90 to $100 \mathrm{~mm}$ long \\
\hline Length / width ratio & $11: 1$ \\
\hline Leaf shape & $\begin{array}{l}\text { Narrow to very narrow oblong, base is } \\
\text { narrow-cuneate, top is obtuse }\end{array}$ \\
\hline $\begin{array}{l}\text { Base angle at 25\% } \\
\text { from base }\end{array}$ & $\begin{array}{l}26^{\circ} \\
\text { Apex angle at } 75 \% \\
\text { from base }\end{array}$ \\
\hline $\begin{array}{l}\text { Venation } \\
\text { Very elongate elliptic mesh, arching at } \\
\text { moderate angle from midrib: at an angle } \\
\text { of } 32^{\circ}, \text { reaching } 43^{\circ} \text { in the middle of the } \\
\text { lamella, and an angle of } 51^{\circ} \text { at the } \\
\text { margin }\end{array}$ \\
\hline $\begin{array}{l}17 / \text { cm. } \\
\text { Reaches apex; midrib is } 1.5 \text { mm wide at } \\
\text { Midrib }\end{array}$ \\
$\begin{array}{l}\text { base of lamella, and tapers towards the } \\
\text { apex }\end{array}$ \\
$\begin{array}{l}\text { Beginsel (1284), Ons Huis ( } 780), \\
\text { the Normandien Pass (Figure } 1 \text { ). }\end{array}$ \\
\hline
\end{tabular}

Morphotype Pnc6 (Figure 41, m):

\begin{tabular}{ll}
$\begin{array}{l}\text { Amount of } \\
\text { specimen were found. } \\
\text { specimens found }\end{array}$ & Eighteen samples of this identifiable \\
\hline Leaf size & $75 \mathrm{~mm}$ long \\
\hline Length / width ratio & $6.5: 1$ \\
\hline $\begin{array}{l}\text { Leaf shape } \\
\text { Narrowly oblong, base cuneate, apex } \\
\text { obtuse-rounded }\end{array}$ & $\begin{array}{l}19^{\circ} \\
\text { Base angle at } 25 \%\end{array}$ \\
$\begin{array}{l}\text { from base } \\
\text { Apex angle at } 75 \%\end{array}$ \\
$\begin{array}{l}\text { Eem base } \\
\text { Venation }\end{array}$ \\
$\begin{array}{l}\text { alliptical meshes; inclined at moderate } \\
\text { the middle of the lamella, and } 55^{\circ} \text { at the } \\
\text { leaf margin. Frequently anastomoses, } \\
2 \text { to } 4 \text { times, across lamella. }\end{array}$
\end{tabular}




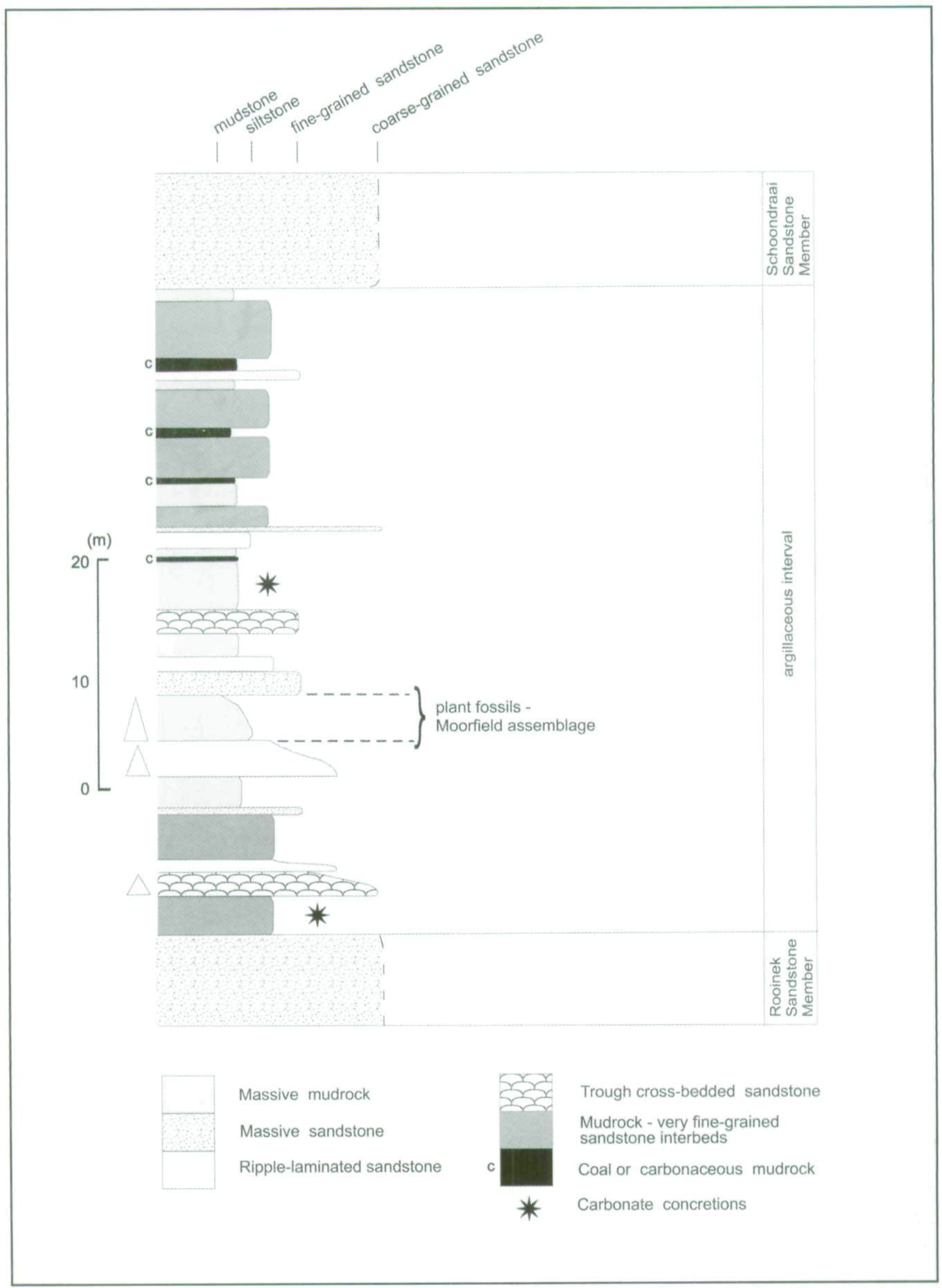

Figure 5. Detailed sedimentary profile measured through the argillaceous interval separating Rooinek and Schoondraai (Sandstone) Members, Normandien Formation, on the farm Moorfield (9194). Modified after Groenewald (1989), based on current field work. Note two subdivisions: lower c. $30 \mathrm{~m}$ which contains thicker and more common sandstones and which includes the fossil localities, and upper c. 20 $\mathrm{m}$ of argillaceous rocks with fewer sandstones and with carbonaceous mudrocks. 
Venation density

\begin{tabular}{ll}
\hline Midrib & $\begin{array}{l}\text { Reaches apex but very faint; } 1 \mathrm{~mm} \text { wide } \\
\text { at base of lamella, and tapers persistently } \\
\text { towards apex. }\end{array}$ \\
\hline Localities & Beginsel (1284), Ons Huis (780), La \\
& Hochs Hoek (262) and on the \\
& Normandien Pass (Figure 1) \\
\hline
\end{tabular}

Morphotype Pnc7 (Figure 4n, o):

\begin{tabular}{|c|c|}
\hline $\begin{array}{l}\text { Amount of } \\
\text { identifiable } \\
\text { specimens found }\end{array}$ & Seventeen samples \\
\hline Leaf size & $120 \mathrm{~mm}$ \\
\hline Length / width ratio & $3.6: 1$ \\
\hline Leaf shape & Elliptic, base cuneate, apex obtuse \\
\hline $\begin{array}{l}\text { Base angle at } 25 \% \\
\text { from base }\end{array}$ & $46^{\circ}$ \\
\hline $\begin{array}{l}\text { Apex angle at } 75 \% \\
\text { from base }\end{array}$ & $46^{\circ}$ \\
\hline Venation & $\begin{array}{l}\text { Inclined at a moderate angle: } 20^{\circ} \text { at the } \\
\text { midrib, } 39^{\circ} \text { in the middle of the lamella } \\
\text { and at } 43^{\circ} \text { at the lamella margin. }\end{array}$ \\
\hline \multicolumn{2}{|l|}{ Venation density } \\
\hline \multicolumn{2}{|l|}{ Midrib } \\
\hline Localities & $\begin{array}{l}\text { Seventeen samples of this leaf were } \\
\text { found and collected on the farms } \\
\text { Beginsel (1284), Ons Huis ( } 780) \text {, Insigt } \\
\text { (1416) Christina ( } 90) \text {, and on the } \\
\text { Normandien Pass (Figure 1). }\end{array}$ \\
\hline
\end{tabular}

\section{Farm Moorfield (9194) Glossopteris fossil assemblage}

As with the previous fossil assemblage at Christina, that at Moorfield as described here, is centred on this farm but fossils were also identified and collected from surrounding farms (Figure 1). This fossil assemblage comprises, stratigraphically, of a argillaceous zone between the medial Rooinek and the upper Schoondraai Member sandstones within the Normandien Formation (Figure 2). This argillaceous interval is approximately $50 \mathrm{~m}$ thick at Moorfield and comprises predominantly of an alternation of mudrocks with thin sandstone interbeds. The latter are about 1 to $5 \mathrm{~m}$ thick, mainly fine-grained (with rare coarse-grained sandstones) and exhibit trough cross-bedding, ripple laminated sandstones and lesser massive sandstones (Figure 5). The lower approximately $30 \mathrm{~m}$ of the argillaceous interval between the Rooinek and Schoondraai Members has thicker and more common sandstone interbeds, whereas the upper c. $20 \mathrm{~m}$ is much less sandy, with predominant mudrocks and lesser carbonaceous shales / coal beds (Figure 5). The main Glossopteris plant assemblage was collected from the middle of the former, sandier lower $30 \mathrm{~m}$ of the argillaceous interval (Figure 5).

The lowermost $10 \mathrm{~m}$ of this interval consists of greygreen interbedded mudrocks and lesser fine-to coarsegrained that display soft sediment deformation and trough cross-bedding with set thickness of $30 \mathrm{~cm}$.
Lycopod stem impressions occur within the sandstones, but no leaf impressions are absent. The former are identified from the leaf attachment scars; these have lengthened rhombohedral shapes in the lower (thicker) parts of the preserved stems, and at higher levels of the stems, the scars become more lozenge-shaped. Locally, these Lycopod impressions are up to $2 \mathrm{~m}$ in length. The overlying $6 \mathrm{~m}$ of the stratigraphic succession at Moorfield comprises fine-grained sandstones (massive to rippled) with mudrocks; silicified Dadoxylon fossil wood is found within this portion, but these trunk portions are not in situ.

Above this unit, is a $5 \mathrm{~cm}$ thick pink-coloured, finely laminated, very fine-grained silty-mudstone bed, with densely packed Glossopteris leaves (Figure 5). Plant fossils found here include: Morphotype Pnm1, Morphotype Pnm2, Morphotype Pnm3. The following unit, c. $5 \mathrm{~m}$ thick and consisting of yellow-coloured massive mudstone, contains well preserved but less densely packed leaves belonging to Glossopteris and several other genera (Rigbya arberoides, Sphenophyllum speciosum, L. inbluzanensis). Plants identified in the informal "Moorfield assemblage zone" (and described briefly below) are: Equisetum* ${ }^{*}$, Morphotype Pnm1, Morphotype Pnm2*, Morphotype Pnm3, Morphotype Pnc4* ${ }^{*}$, Morphotype Pnc5*, Morphotype Pnc6*, Rigbya arberioides, and Sphenophyllum speciosum $\left({ }^{*}=\right.$ also form part of the "Christina assemblage zone").

Morphotype Pnm1 (Figure 6a):

\begin{tabular}{|c|c|}
\hline $\begin{array}{l}\text { Amount of } \\
\text { identifiable } \\
\text { specimens found }\end{array}$ & Seven \\
\hline Leaf size & $\begin{array}{l}\text { Leaf size: small, measuring } 30 \text { to } 40 \mathrm{~mm} \\
\text { in length and not wider than } \\
7 \mathrm{~mm}\end{array}$ \\
\hline Length / width ratio & $5: 1$ \\
\hline Leaf shape & Oblong-obvate, always arched \\
\hline $\begin{array}{l}\text { Base angle at } 25 \% \\
\text { from base }\end{array}$ & $16^{\circ}$ \\
\hline $\begin{array}{l}\text { Apex angle at } 75 \% \\
\text { from base }\end{array}$ & $35^{\circ}$ \\
\hline Venation & $\begin{array}{l}\text { Are very elongated and elliptical, inclined } \\
\text { at a steep angle to the midrib }-19^{\circ} \text {, in } \\
\text { the centre of the lamella it reaches } 27^{\circ}\end{array}$ \\
\hline Venation density & 40 and 46 per $\mathrm{cm}$ \\
\hline Midrib & $\begin{array}{l}\text { Is not well defined, and appears not to } \\
\text { reach the apex }\end{array}$ \\
\hline Localities & $\begin{array}{l}\text { The farms Moorfield (9194), Horingkloof } \\
\text { (330), Eden (72) }\end{array}$ \\
\hline
\end{tabular}

Morphotype Pnm2 (Figure 6c):

\begin{tabular}{ll}
\hline $\begin{array}{l}\text { Amount of } \\
\text { identifiable } \\
\text { specimens found }\end{array}$ & Seven specimens were found \\
\hline Leaf size & $8.5 \mathrm{~cm}$ long \\
\hline Length / width ratio & $7: 1$ \\
\hline Leaf shape & $\begin{array}{l}\text { Very narrow obovate, tip obtuse, base } \\
\text { cuneate }\end{array}$ \\
\hline
\end{tabular}



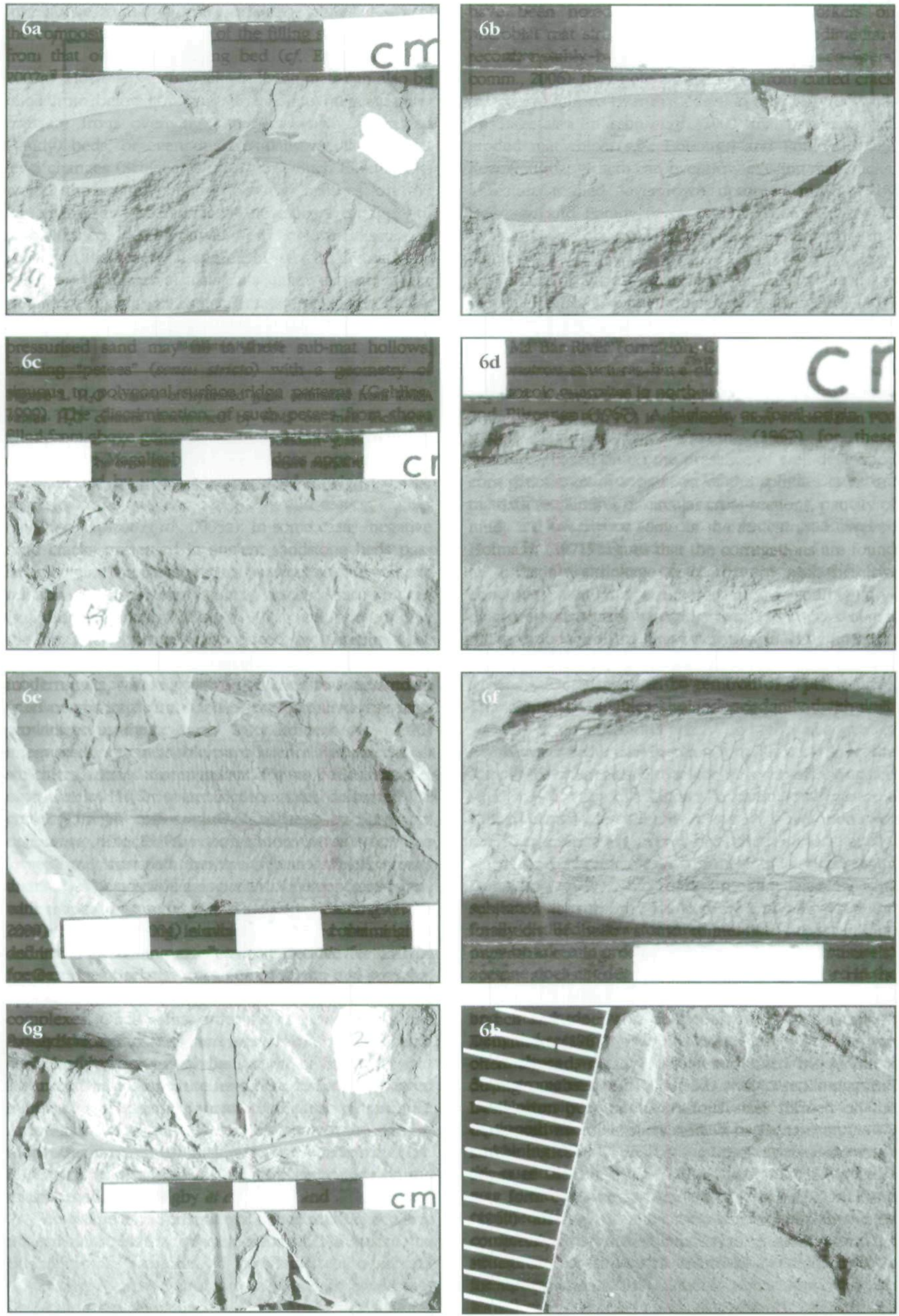


\begin{tabular}{ll}
\hline $\begin{array}{l}\text { Base angle at } 25 \% \\
\text { from base }\end{array}$ & $13^{\circ}$ \\
\hline $\begin{array}{l}\text { Apex angle at } 75 \% \\
\text { from base }\end{array}$ & $75^{\circ}$ \\
\hline Venation & $\begin{array}{l}\text { Narrow elongated elliptic; anastomoses } \\
2 \text { to } 3 \text { times across lamella }\end{array}$ \\
\hline Venation density & 18 per cm \\
\hline Midrib & Not well defined, and reaches the apex \\
\hline Localities & $\begin{array}{l}\text { Moorfield (9194), Insigt (1416), } \\
\text { Horingkloof (330), Eden (72), Beginsel } \\
(1284), \text { Molen Riviers Oorsprong (614) } \\
\text { and on Normandien Pass (Figure 1) }\end{array}$ \\
\hline
\end{tabular}

Morphotype Pnm3: Specimen number: MCL96 / $2 / 3$

\begin{tabular}{ll}
\hline $\begin{array}{l}\text { Amount of } \\
\text { identifiable } \\
\text { specimens found }\end{array}$ & Seven specimens were found \\
\hline Leaf size & Leaves incomplete, width 19 to $21 \mathrm{~mm}$ \\
\hline Length / width ratio & \\
\hline Leaf shape & \\
\hline $\begin{array}{l}\text { Base angle at 25\% } \\
\text { rom base }\end{array}$ & \\
\hline $\begin{array}{l}\text { Apex angle at } 75 \% \\
\text { from base }\end{array}$ & $\begin{array}{l}\text { Frequently anastomoses, forming a } \\
\text { coarse open reticulum; mesh is coffin- } \\
\text { Venation }\end{array}$ \\
\begin{tabular}{ll}
16 per cm \\
\hline Venation density
\end{tabular} \\
\hline $\begin{array}{l}\text { Midrib } \\
\text { Locality's }\end{array}$ \\
$\begin{array}{l}\text { Luiperdskloof and Moorfield (9194), and } \\
\text { on the Normandien Pass (Figure 1) }\end{array}$ \\
\hline
\end{tabular}

Rigbya arberioides (Lacey 1975) (Figure 6g): Specimen number: MCL99 / 1/1/1.

Female fructification, consists of a stalk, with terminal flagellate aggregation of seed- bearing scales or perhaps a one-seeded cupule. Stalk: Curved, $80 \mathrm{~mm}$ long and $1 \mathrm{~mm}$ wide; expanded at distal end up to $2 \mathrm{~cm}$ wide then dividing repeatedly to form dorsiventral flagellate cluster of four well formed and two misformed distal scales, the misformed scales(cupule) are probably due to preservation. Scales(cupule): length between 6 to $8 \mathrm{~mm}$; width 4 to $5 \mathrm{~mm}$; base of scale(cupule) is narrow, becoming elongated, and terminating in two pointed lobes. Localities: Four specimens were found, on the farms Molen Riviers Oorsprong (614), Moorfield (9194), Insigt (1416) (Figure 1).

\section{Spbenopbyllum speciosum (Royal 1839)(McClelland 1850) (Figure 6h):}

Specimen number: MCL99 / 1/ $2 / 1$. The leaflets were not complete. Leaflets: obovate, entire distal margin rounded; two leaflets of unequal size were found. Localities: Seven samples of Sphenophyllum speciosum were found on the farms Moorfield (9194), Molen Riviers Oorsprong (612) and Middelste (643).

\section{Discussion}

\section{Christina and Moorfield informal assemblage zones}

The fossil assemblage were traced over an aria of 840 square kilometres. The fossil assemblage were found on the farms Christina (90), Moorfield (9194), Beginsel (1284), Ons Huis (780), La Hochs Hoek (262), Insigt (1416), and on the Normandien and Millers Pass along the Drakensberg escarpment

\section{Depositional conditons of Normandien Formation sedimentary rocks and palaeoenvironment pertinent to plant fossils}

Previous workers on Beaufort Group palaeoenvironments are in overall agreement that high sinuosity fluvial systems in which broad and commonly partly arid (or at least strongly seasonal) floodplains were predominant over relatively restricted channel sandstone belts, were characteristic of the depositional setting (e.g., Stear, 1980; 1983; Smith, 1980; 1987; 1990; Smith et al., 1993; Rubidge, 1995). An exception to this viewpoint applies to deposition during thr early Triassic when sandy braided fluvial systems formed the Katberg formation (e.g., Hiller and Stavrakis, 1979). In the northeastern corner of the Karoo basin, including the present study area, a shallow remnant of the Ecca epeiric sea persisted into lower Beaufort times (Smith et al., 1993), and a continuation of typical northeasterntype Ecca fluviodeltaic systems within this region is supported by the upward-coarsening mudrocksandstone cycles of the lowermost Frankfort Member of the Normandien Formation (Groenewald, 1989). The succeeding Beaufort (Normandien Formation) interval in the study area, comprising of three argillaceous intervals, where by the lower two (respectively containing the Christina and Moorfield "assemblage zones" discussed above), separated by the Rooinek Sandstone Member, reflect small channel sandstone systems meandering across predominant muddy-silty floodplains with localised swamps (Groenewald, 1989; Catuneanu et al., 1998). Hobday (1978) interprets the eastern Beaufort fluvial succession as reflecting mixed-load high sinuosity channel systems.

Figure 6. Photographs of plant fossils (proposed "Moorfield assemblage zone"), obtained from the farm Moorfield (9194) unless otherwise noted, in the argillaceous succession between the Rooinek and Schoondraai Members, Normandien Formation, Beaufort Group: (a) leaf impressions of Morphotype Pnm1; (b) Very faint venation pattern from Morphotype Pnm1; (c) Leaf impression of Morphotype Pnm2; (d) Venation of Morphotype Pnm2; (e) Leaf impression of Morphotype Pnm3; (f) Venation of Morphotype Pnm3; (g) Impression of Rigbya arberioides; (h) Impression of Sphenophyllum speciosum. 


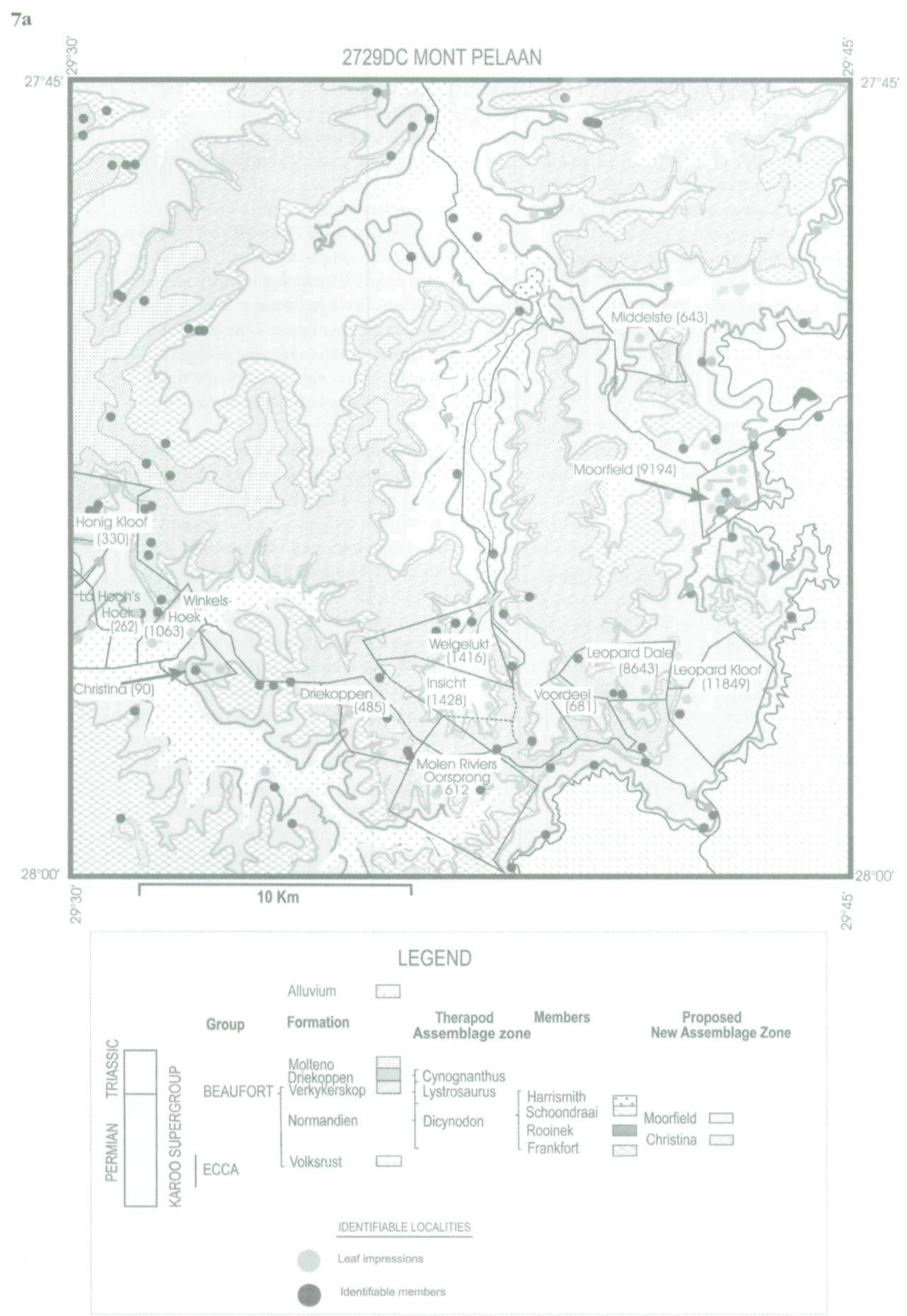


$7 \mathbf{b}$

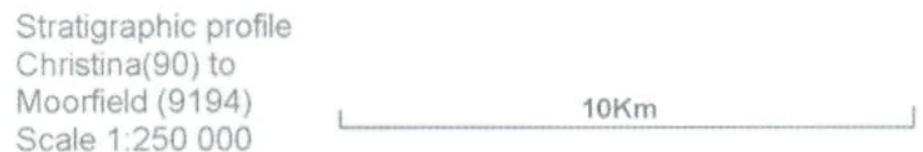

Scale 1:250000

\section{Glossopteris site on the farm}

Christina (90)Christina

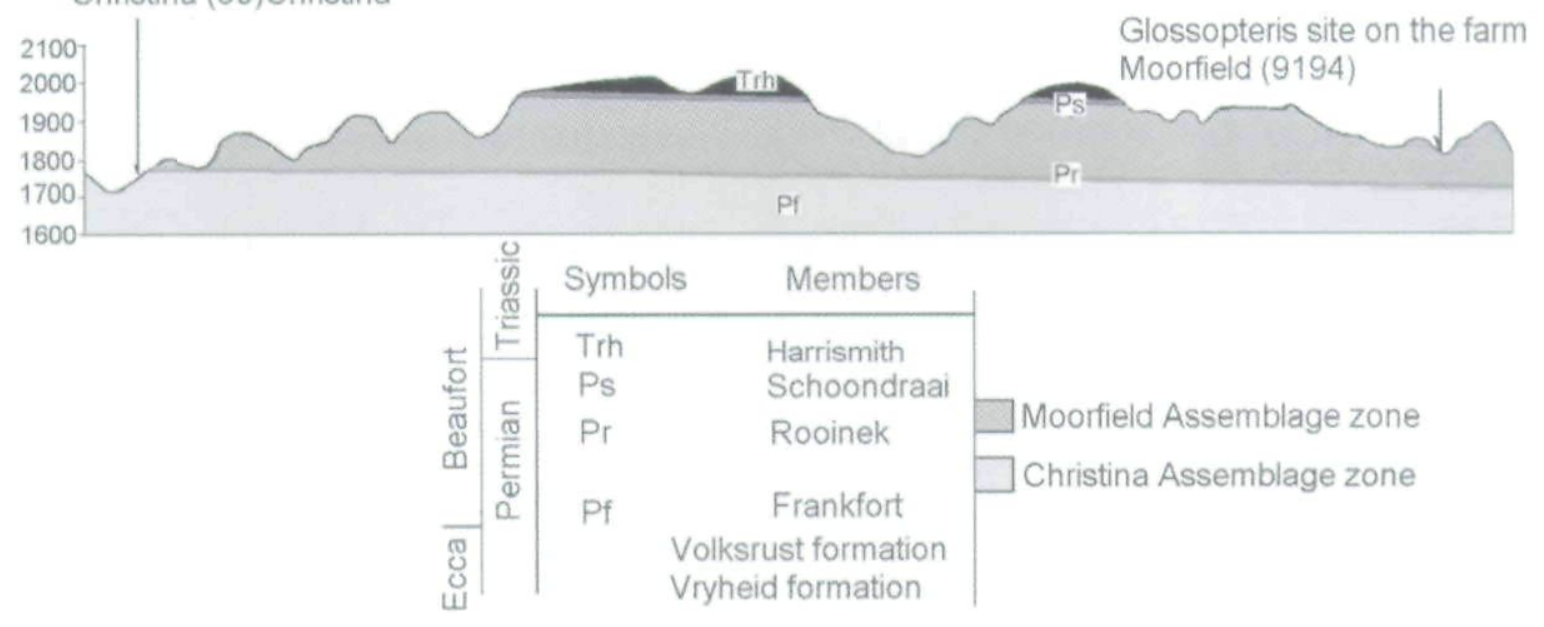

Figure 7. (a) Map of the study area and surroundings, illustrating the application of the Christina and Moorfield plant fossil "assemblage zones" as a regional mapping tool within the Normandien Formation, northeastern Karoo basin. (b) Profile through mapped area, showing stratigraphic location of the two proposed plant fossil assemblage zones, based on fossils collected at the farms Christina and Moorfield and adjacent properties.

Within the argillaceous interval separating Frankfort and Rooinek Sandstones ("Christina assemblage zone"), Groenewald (1989) suggests that the lower portion depicts a continuation of delta plain sedimentation, grading into an upper meandering river palaeoenvironment. At the Christina fossil assemblage discussed here, the measured sedimentary profile is just below the Rooinek Member, and cannot be directly linked to high sinuosity fluvial deposition. The upwardcoarsening mudrock-sandstone cycles here (Figure 3) are only several decimetres thick, with laminated mudrocks passing up into fine-grained, ripple-marked sandstones; this rather suggests weak currents transporting fine sands into a shallow basin where muds settled out of suspension. The succession at Christina from which the plant fossils were obtained thus probably represents weak fluvial currents, possibly related to distal crevasse-splays and late-stage flood deposition, into shallow pools and small lakes on the meandering fluvial floodplain. The Christina leaf fossils themselves are very closely packed and commonly fragmented, within the upper four cycles' basal mudrocks. The fragmentation supports transport of vegetation debris of the Glossopteris fauna, rather than in situ vegetation growth on the floodplains; this is in agreement with the suggested flood deposition (implicit within a meandering river model) of the enclosing mudrocks, and with evidence for some aridity or at least strong seasonality affecting Beaufort floodplain palaeoenvironments (e.g., Smith et al., 1993; Rubidge, 1995; Catuneanu et al., 1998, 2005).

The second argillaceous interval in the Normandien Formation, that separating the medial Rooinek and upper Schoondraai Members and within which the "Moorfield fossil assemblage" was collected, is interpreted to reflect analogous palaeoenvironmental conditions to those outlined above ( $c f$., Hobday, 1978; e.g., Groenewald, 1989). Here a lower, more sandy $30 \mathrm{~m}$ (including the fossil assemblage) is succeeded by about $20 \mathrm{~m}$ in which mudrocks predominante along with subordinate carbonaceous shales and coal beds (Figure 6). Carbonate concretions within the lower $30 \mathrm{~m}$ attest to some semi aridity on the floodplains (Groenewald, 1989), but the upper portion would appear to have enjoyed a more humid palaeoclimate, with coal swamps developing locally. The lower, sandy, $30 \mathrm{~m}$ thick part of the argillaceous succession studied at Moorfield contains common lenticular feldspathic 
sandstone beds displaying trough cross-bedding, soft sediment deformation structures and with Lycopod stem impressions and transported segments of silicified Dadoxylon tree trunks (Figure 5). Together, these observations suggest higher energy mixed load meandering fluvial systems, with immature feldspathic detritus transported rapidly from source areas, with enough energy in the flood conditions to transport large tree trunks (up to $2 \mathrm{~m}$ in length - cf. preserved Lycopod stem impressions); soft sediment deformation structures indicate rapid deposition as would occur during floods. The more sandy nature of this lower portion of the succession studied at Moorfield (Figure 5) indicates a greater concentration of sandy channel systems and possibly also of crevasse-splay wedges which prograded onto the partly arid floodplains. The uppermost c. $5 \mathrm{~m}$ of this higher energy $30 \mathrm{~m}$-thick succession is essentially argillaceous (Figure 5) and contains the leaf fossils of the Moorfield "assemblage zone", comprising a lower c. $5 \mathrm{~cm}$ of densely packed leaves, followed by c. $5 \mathrm{~m}$ of mudrocks with more dispersed leaf impressions. These deposits logically suggest a more distal part of the underlying, sandy flood deposits. A more seasonal palaeoclimate for this lower $30 \mathrm{~m}$ succession (cf., carbonate concretions; Figure 5) is in accord with the inferred flood deposition. The upper c. $20 \mathrm{~m}$ part of the Moorfield argillaceous succession, with evidence for coal swamps on meandering fluvial floodplains, can be interpreted as reflecting a more stable and wetter palaeoclimate.

\section{Plant fossil-based biostratigraphic subdivision and mapping of the Normandien Formation}

Fossils of the proposed informal "Christina assemblage zone" (defined by: Morphotype Pnc1, Morphotype Pnc2, Morphotype Pnc3 and Morphotype Pnc4) underlie the Rooinek Member sandstones and are thus older than those of the succeeding argillite zone (informal "Moorfield assemblage zone", defined by: Morphotype Pnm1, Morphotype Pnm3, Rigbya arberioides and Sphenophyllum speciosum), separating Rooinek and Schoondraai sandstones. Fossils common to both proposed assemblage zones (Equisetum, Morphotype Pnc5, Morphotype Pnc6 and Morphotype Pnc7) can obviously not be employed for biostratigraphic subdivision.

If the Rooinek Member were a well-defined and continuous arenaceous unit of uniform character, there would be no need for biostratigraphic distinction of the argillaceous intervals beneath and above it. However, the Rooinek Member comprises essentially lenticular sandstones, of variable composition and grain sizes extending over large lateral distances, and since both under- and overlying argillaceous intervals have common lenticular sandstones within them, as does the Rooinek itself contain interbedded mudrocks, stratigraphic definition within the study area often becomes problematic. For this reason, the two suggested informal assemblage zones, the lower Christina and the upper Moorfield zones, provide an easy means to determine stratigraphic position within the field. The leaf fossils described here and which define these zones are common enough in the field, that the two argillaceous successions either side of the Rooinek Member can be mapped with confidence, as shown in Figure 7. As can be seen from this remapping of the area, the boundary between the two plant fossil assemblage zones can be determined at many assemblages, enabling accurate mapping of the detailed subdivisions of the Normandien Formation stratigraphy.

\section{Conclusions}

The present study has identified plant fossils belonging to the Glossopteris flora collected at two new assemblages. The leaf fossils identified are illustrated to enable correlation with other known assemblages.

Within the Late Permian Normandien Formation (Beaufort Group, Karoo Supergroup) which correlates, as a whole, with the Dicynodon reptile assemblage zone, with the exeption of the upper most Harrysmith member (cf. Rubidge, 1995), further biostratigraphic subdivision has been shown to be possible, based on two informal fossil plant assemblage zones, those centred on the farms Christina (lower Normandien Formation, argillaceous succession separating lowermost Frankfort and medial Rooinek Sandstone Members) and Moorfield (upper Normandien Formation, argillaceous succession separating medial Rooinek and upper Schoondraai Sandstone Members). The "Christina assemblage zone" is defined by Morphotype Pnc1, Morphotype Pnc2, Morphotype Pnc3 and Morphotype Pnc4, and that at Moorfield by Morphotype Pnm1, Morphotype Pnm3, Rigbya arberioides and Sphenophyllum speciosum. These two informal fossil plant assemblage zones have been successfully applied in the remapping of a large area of the Beaufort Group in the chosen study area (Figure 7).

\section{Acknowledgements}

A special note of appreciation is expressed to Professor J.V. van Greuning, Dept. of Botany, University of Pretoria, for his advice and support in photographing the leaf impressions. Mr. Louis Cronje is thanked for his kindness in providing a base for field work at the farm Moorfield over the past seven years. The South African Police Services radio technical services stationed at Newcastle, and especially Inspector Etienne Claassen, are thanked for unselfish cooperation and for enabling contact with the farmers in the area to be established. To all the local farmers who granted access to their properties, my sincere thanks. Members of the South African Society for Amateur Palaeontology are thanked for their assistance during field work on the farms Moorfield and Christina. The author would like to gratefully acknowledge Johann Neveling and Francois Durand who reviewed and greatly improved this manuscript. 


\section{References}

Altermann, W. (2002). The evolution of life and its impact on sedimentation. In: W. Altermann and P. L. Corcoran (Editors). Precambrian sedimentary environments: a modern approach to ancient depositional systems. Blackuell, Oxford, United Kingdom, 15-32.

Anderson, J.M. and Anderson H.M. (1985). Palaeoflora of Southern Africa: Prodromus of South African megafloras, Devonian to Lower Cretaceous. Balkema, Rotterdam, The Netberlands, 423p.

Anderson, J.M. and Anderson, H.M. (1993). Terrestrial flora and fauna of the Gondwanan Triassic. Part 2 - Co-evolution. In: S.G. Lucas and M. Morales (Editors). The Nonmarie Triassic. New Mexico Museum of Natural History and Science Bulletin, 3, 13-25.

Anderson, J.M. and Anderson, H.M. 1997). Towards new paradigms in Permo-Triassic Karoo palaeobotany (and associated faunas) through the past years. Palaeontologia Africana, 33, 11-21.

Anderson, J.M., Anderson, H.M., Archangelsky, S., Bamford, M., Chandra, S., Dettmann, M., Hill, R., McLoughlin, S. and Rösler, O. (1999). Patterns of Gondwana plant colonisation and diversification. Journal of African Earth Sciences, 28, 145-167.

Aspler, L.B. and Chiarenzelli, J.R. (1998). Two Neoarchean supercontinents? Evidence from the Paleoproterozoic. Sedimentary Geology, 120, 75-104.

Bamford, M.K. (1999). Permo-Triassic fossil woods from the South African karoo Basin. Palaeontologia Africana, 35, 25-40,

Bond, G.C., Christie-Blick, N. and Kominz, M.A. (1984). Break-up of a supercontinent between $625 \mathrm{Ma}$ and $555 \mathrm{Ma}$ : new evidence and implications for continental histories. Earth and Planetary Science Letters, 70, 325-345.

Cadle, A.B. (1974). A subsurface sedimentological investigation of parts of the Ecca and Beaufort Groups in the northeastern Karoo Basin. Unpublished MSC Thesis, University of Natal, Pietermaritzburg, South Africa, 217pp.

Cairncross, B. (2001). An overview of the Permian (Karoo) coal deposits of southern Africa. Journal of African Earth Sciences, 33, 529-562.

Catuneaun, O. and Bowker, D. (2001). Sequence stratigraphy of the Koonap and Middleton fluvial formations in the Karoo foredeep, South Africa. Journal of African Eartb Sciences, 33, 579-595.

Catuneanu, O., Hancox, P.J. and Rubidge, B.S. (1998). Recoprocal flexural behaviour and contrasting stratigraphies: a new basin development model for the Karoo retroarc foreland system, South Africa. Basin Researcb, 10. $417-439$.

Catuneanu, O., Wopfner, H., Eriksson, P.G., Cairncross, B., Rubidge, B.S., Smith, R.M.H. and Hancox, P.J. (2005). The Karoo basins of south-central Africa. Journal of African Eartb Sciences, 43, 211-253.

Condie, K.C. (2002). The supercontinent cycle: are there two patterns of cyclicity? Journal of African Earth Sciences, 35, 179-183.

Dalziel, I.W.D., Mosher, S. and Gahagan, L.M. (2000). Laurentia-Kalahari collision and the assembly of Rodinia. Journal of Geology, 108, 499-513.

Erwin, D.H. (1994). The Permo-Triassic extinction. Nature, 367, 231-236.

Erwin, D.H. (1999). Biospheric perturbations during Gondwanan times: from the Neoproterozoic-Cambrian radiation to the end-Permian crisis. Journal of African Earth Sciences, 28, 115-127.

Frimmel, H.E., Fölling, P.G. and Eriksson, P.G. (2002). Neoproterozoic tectonic and climatic evolution recorded in the Gariep Belt, Namibia and South Africa. Basin Research, 14, 55-67.

Groenewald, G.H. (1989). Stratigrafie en sedimentologie van die Groep Beaufort in die Noordoos-Vrystaat, Bulletin of the Geological Survey of South Africa, 96, 62pp.

Grunow, A.M. (1999), Gondwana events and palaeogeography: a palaeomagnetic review. Journal of African Earth Sciences, 28, 53-69.

Gurnis, M. (1988). Large-scale mantle convection and the aggregation and dispersal of supercontinents. Nature, 332, 695-699.

Hancox, P.J. (1998), A stratigraphic, sedimentological and palaeoenvironmental synthesis of the Beaufort-Molteno contact in the Karoo Basin. Unpublished PbD Thesis, University of the Witwatersrand, Jobannesburg, Soutb Africa, 380pp.

Hancox, P.J. and Rubidge, B.S. (1997). The role of fossils in interpreting the development of the Karoo Basin. Palaeontologia Africana, 33, 41-54.

Hancox, P.J. and, Rubidge, B.S. (2001). Breakthroughs in the biodiversity, biogeography, biostratigraphy, and basin analysis of the Beaufort Group. Journal of African Earth Sciences, 33, 563-577.
Hiller, N., Stavrakis, N. (1979). Distal alluvial fan deposits in the Beaufort Group of the eastern Cape. Abstract, 18th Congress of the Geological Society of South Africa, Port Elizabeth, 2, 113-120.

Hobday, D.K. (1978), Fluvial deposits of the Ecca and Beaufort Groups in the eastern Karoo basin, southern Africa. In: A. D. Miall (Editor). Fluvial Sedimentology. Canadian Society of Petroleum Geologists, Memoir. 5. 413-429.

Hoffman, P.F. (1988). United plates of America, the birth of a craton: Early Proterozoic assembly and growth of Laurentia. Annual Revieus of the Earth and Planetary Sciences, 16, 543-603.

Hoffman, P.F. (1999). The break-up of Rodinia, birth of Gondwana, true polar wander and the snowball earth. Journal of African Earth Sciences, 28, $17-43$.

Johnson, M.R., van Vuuren, C.J., Hegenberger, W.F., Key, R. and Shoko, U. (1996). Stratigraphy of the Karoo Supergroup in Southern Africa: an overview. Journal of African Earth Sciences, 23, 3-15.

Kitching, J.W. (1977). The distribution of the Karroo vertebrate fauna. Bernard Price Institute for Palaeontological Research, University of the Witwatersrand, Memoir, 1, 131pp.

Kitching, J.W. (1978). The stratigraphic distribution and occurrence of South African fossil Amphibia in the Beaufort Beds. Palaeontologia Africana. 21, 101-112.

Kovacs-Endrody, E. (1991). On the Late Permian age of Ecca Glossopteris floras in the Transvaal Province with a key to and description of tweny five Glossopteris species, Memoir of the Geological Survey of Soutb Africa, 77. $111 \mathrm{pp}$.

Lucas, S.G. (1998). Global tetrapod biostratigraphy and biochronology. Palaeogeography. Palaeoclimatology, Palaeoecology, 143, 347-384

MacRae, C.S. and, Aitken, G.A. (1997). Contributions in the field of palaeopalynology at the Bernard Price Institute, past, present and furue. Palaeontologia Africana, 33, 37-40.

Marsh, J.S., Hooper, P.R., Rehacek, J., Duncan, R.A. and Duncan, A.R. (1997). Stratigraphy and age of Karoo basalts of Lesotho and implications for correlations within the Karoo Igneous Province. In: J.J. Mahoney and M.F. Coffin (Editors). Large Igneous Provinces: Continental, Oceanic, and Planetary Flood Volcanism. American Geophysical Union, Washington, D.C., Geophysical Monograph, 100, 247-272.

McMenamin, M.A.S, and McMenamin, D.L.S. (1990). The Emergence of Animals: The Cambrian Breakthrough. Columbia University Press, Neu York, United States of America, 217pp.

Meert, J.G. and Powell, C.McA. (2001). Editorial: Assembly and break-up of Rodinia: introduction to the special volume. Precambrian Research, $110,1-8$.

Pigg, K.B. and Trivett, M.L. (1994). Evolution of the glossopterid gymnosperms from Permian Gondwana. Journal of Plant Research, 107, 461-477

Piper, J.D.A. (2000). The Neoproterozoic Supercontinent: Rodinia or Palaeopangaea? Earth and Planetary Science Letters, 176, 131-146.

Rogers, J.J.W. (1996). A history of the continents in the past three billion years. Journal of Geology, 104, 91-107.

Rubidge, B.S. (editor) (1995). Biostratigraphy of the Beaufort Group (Karoo Supergroup). South African Committee for Stratigraphy, Biostratigraphic Series, 1, 46pp.

Scotese, C.R. (1997). Paleogeographic Atlas, Paleomap Project (Report 900497). Unitersity of Texas at Arlington, Arlington, Texas, United States of America.

Shishkin, M.A., Rubidge, B.S. and Hancox, P.J. (1995). Vertebrate biozonation of the Upper Beaufort Series of South Africa - a new look on correlation of the Triassic biotic events in Euramerica and southern Gondwana. In: Sixth Symposium on Mesozoic Terrestrial Ecosystems. Cbina Press, Beijing, China, 39-41.

Smith, R.M.H. (1980). The lithology, sedimentology and taphonomy of floodplain deposits of the Lower Beaufort (Adelaide Subgroup) strata near Beaufort West. Transactions of the Geological Society of South Africa. 83, 399-413.

Smith, R.M.H. (1987). Helical burrow casts of therapsid origin from the Beaufort Group (Permian) of South Africa, Palaeogeograpby, Palaeoclimatology, Palaeoecology, 60, 155-170.

Smith, R.M.H. (1990), A review of stratigraphy and sedimentary environments in the Karoo Basin of South Africa. Journal of African Earth 
Sciences, 10, 117-137.

Smith, R.M.H., Eriksson, P.G. and Botha, W.J. (1993). A review of stratigraphy and sedimentary environments of the Karoo basins of southern Africa. Journal of African Earth Sciences 16, 143-169.

Stear, W.M. (1980). The sedimentary environment of the Beaufort Group Uranium district near Beaufort west, South Africa. Unpublished PbD thesis, University of Port Elizabeth, South Africa, 188pp.

Stear, W.M. (1983). Morphological characteristics of ephemeral stream channel and overbank splay sandstone bodies in the Permian Lower Beaufort Group, Karoo basin, South Africa. In: J.D. Collinson and J. Lewin (Editors). Modern and ancient fluvial systems. International Association of Sedimentologists, Special Publication 6, Blackwell, Oxford, United Kingdom, 6, 405-420.

Turner, B.R. (1986). Tectonic and climatic controls on continental depositional facies in the Karoo Basin of northern Natal, South Africa. Sedimentary Geology, 46, 231-257.

Turner, B.R. (1999). Tectonostratigraphical development of the Upper Karoo foreland basin: orogenic unloading versus thermally-induced Gondwana rifting. Journal of African Earth Sciences, 28, 215-238.

Van Dijk, D.E., Hobday, D.K. and Tankard, A.J. (1978). Permo-Triassic lacustrine deposits in the eastern Karoo Basin, Natal, South Africa. In: A. Matter and M.E. Tucker (Editors). Modern and ancient lake sediments. International Association of Sedimentologists, Special Publication, Blackwell, Oxford, United Kingdom, 2, 225-239.

Williams, G.E. (1998). Precambrian tidal and glacial clastic deposits: implications for Precambrian Earth-Moon dynamics and palaeoclimate. Sedimentary Geology, 120, 55-74.

Williams, H., Hoffman, P.F., Lewry, J.F, Monger, J.W.H. and Rivers, T. (1991). Anatomy of North America: thematic portrayals of the continent. Tectonophysics, 187, 117-134.

Young, G.M. (2002), Stratigraphic and tectonic settings of Proterozoic glaciogenic rocks and banded iron-formations: relevance to the snowball Earth debate, Journal of African Earth Sciences, 35, 451-466.

Editorial handling: A. Bumby 
Copyright of South African Journal of Geology is the property of Geological Society of South Africa and its content may not be copied or emailed to multiple sites or posted to a listserv without the copyright holder's express written permission. However, users may print, download, or email articles for individual use. 